\title{
The Partial Purification and Properties of Endopolygalacturonase and $\alpha$-L-Arabino- furanosidase secreted by Sclerotinia fructigena
}

\author{
By A. H. FIELDING AND R. J. W. BYRDE \\ Long Ashton Research Station, University of Bristol
}

(Accepted for publication 29 May 1969)

\begin{abstract}
SUMMARY
An endopolygalacturonase (PG) and an $\alpha$-L-arabinofuranosidase (AF) in culture filtrates of the fungus Sclerotinia fructigena were partially purified by ion-exchange chromatography on CM-Sephadex and Ecteola-cellulose columns, and characterized. Molecular weight estimations by gel-filtration and electrophoresis on cellulose acetate strips indicated that both enzymes existed in multiple forms. The PG showed unusual stability to extreme $\mathrm{pH}$ values, to classical inhibitors, and to proteolytic enzymes; in the crude filtrate a bimodal temperature/stability curve was obtained.
\end{abstract}

\section{INTRODUCTION}

The role of pectolytic enzymes in the pathogenicity of fungi and bacteria towards higher plants has been reviewed by Wood (I960) and by Bateman \& Millar (I966). Pectolytic enzymes are believed to be involved in the brown rots of plant tissues caused by three species of the genus Sclerotinia. The importance of 'cytolytic' enzymes in the pathogenicity of fungi was first put forward in the classical paper of de Bary (I886) about $S$. libertiana; Bruschi (cited by Valleau, 19I5) was the first to suggest the action of pectolytic enzymes in a fruit-rotting species. Subsequent work with the brown rot fungi was reviewed by Wormald (1954). Cole (1956), who studied the secretion by $S$. fructigena of extracellular pectolytic enzymes, showed a strong parallel between the plant-macerating properties of his preparations and their ability to decrease the viscosity of pectate solutions. In further studies, however, Cole \& Wood (I96I) concluded that the degree of macerating activity was not always directly related to the degree of polygalacturonase activity alone or together with pectin methyl esterase. They also showed the presence of traces of polygalacturonase in infected apples: an apreciable amount was also detected by Calonge, Fielding, Byrde \& Akinrefon ( I 969).

Much of the earlier work on the pectolytic enzymes of Sclerotinia species and other fungal pathogens was done with crude culture filtrates or with ethanol or acetone precipitates from them; the present work aimed at a fuller purification of the polygalacturonase of $S$. fructigena. During this purification, maceration was found to be associated with a component distinct from polygalacturonase (Byrde \& Fielding، 1962); this was later identified as pectin methyl-trans-eliminase (Byrde \& Fielding, 1968). The presence of an enzyme capable of hydrolysing phenyl- $\alpha$-L-arabinofuranoside, and initially thought to be involved in maceration, was also demonstrated in these preparations (Byrde \& Fielding, 1965) and in infected apple (Calonge et al. 
1969). The secretion of arabanases by plant pathogenic fungi was reported by Japanese workers (e.g. Kaji, Tagawa \& Motoyama, 1965); Fuchs, Jobson \& Wonts (1965) surveyed arabanase production by a range of plant pathogens and drew attention to the relatively high secretion of these enzymes by pathogens of leguminous plants rich in arabans. There have been subsequent reports of the secretion of arabanase by Penicillium species (Bush \& Codner, 1968) and of an $\alpha$-L-arabinofuranosidase by Phytophthora palmivora (Akinrefon, 1968).

The present paper describes the partial purification and some properties of the polygalacturonase (poly- $\alpha$-I,4-galacturonide glycanohydrolase; EC. 3.2.I I 15) and of the $\alpha$-L-arabinofuranosidase ( $\alpha$-L-arabinofuranoside arabinohydrolase) secreted by Sclerotinia fructigena Aderh. \& Ruhl.

\section{METHODS}

Materials. Pectinol Iо м (Rohm and Haas, U.S.A.) was used as a reference source of polygalacturonase. Sodium polypectate (Exchange Lemon Products Co., California), 'Brown Ribbon' pectin (12.5\% methoxyl) (Union Crystalex Gelatine Ltd., London) and $p$-nitrophenyl- $\alpha$-L-arabinofuranoside (Fielding \& Hough, 1965) were used as substrates. For analytical studies, the pectic materials were purified by washing with acidified $80 \%(\mathrm{v} / \mathrm{v})$ ethanol in water, followed by ethanol to remove the acid, and dried with ethanol+ether ( $\mathrm{I}: \mathrm{I}, \mathrm{V} / \mathrm{v}$ ). For chromatographic studies, Araban (KochLight, Colnbrook, Bucks) and apple fibre (Cole \& Wood, 196I) were also used as substrates. Sephadex cross-linked dextrans for gel-filtration and ion-exchange chromatography were obtained from Pharmacia AB, Uppsala. Whatman Ecteola-cellulose powder ET 30 and other modified celluloses were also used. The enzyme inhibitors tested were from commercial sources.

Culture of the fungus. The methods used were as described by Byrde \& Fielding (1968) except that, in some of the earlier work, sporulating cultures were grown on potato plugs soaked for $72 \mathrm{hr}$ in aqueous malic acid solution $(7.5 \%$, w/v) before autoclaving (Wiltshire, 1920).

Concentration of the enzyme. When desirable, the enzymes in the crude culture filtrate were concentrated by partial 'freezing-out' (Dixon \& Webb, I958) or by tannic acid precipitation followed by washing with cold acetone (Shibata \& Nisizawa, 1965). The latter method gave a pale buff-coloured powder which retained high enzyme activities for many months when stored at $4^{\circ}$.

Estimation of enzyme activities. Polygalacturonase (poly- $\alpha$-I ,4-galacturonide glycanohydrolase, PG) (EC. 3.2.I . 15), was estimated by one of three methods: (a) reducing grouip assay, based on the estimation of residual iodine with sodium thiosulphate (Jansen \& MacDonnell, 1945). Activity was expressed as micro-equivalents of reducing groups liberated per min. at $25^{\circ} ;(b)$ viscosity assay, based on the loss of viscosity of aqueous solutions of pectin or sodium polypectate following decrease in chain length (Wood, I955). The test solution comprised aqueous pectin or sodium polypectate solution ( $\mathrm{I} \% \mathrm{w} / \mathrm{v}, 5 \mathrm{ml}$.), appropriate buffer $(2 \mathrm{ml}$.), water $(2 \mathrm{ml}$.) and enzyme preparation ( $\mathrm{I} \mathrm{ml}$.). Activity was expressed as $\mathrm{I} / t$ where $t$ was the time (min.) for $50 \%$ decrease in viscosity; $(c)$ an agar plate assay, as described by Dingle, Reid \& Solomons (I953) was extensively used for semi-quantitative estimations during purification. The external diameter of the white ring obtained on the pectate agar plate was proportional to the 
logarithm of the enzyme concentration over a range of dilutions. Activities were expressed relative to an aqueous solution ( $\mathrm{I} \mathrm{mg} . / \mathrm{ml}$.) of Pectinol $10 \mathrm{M}$, defined arbitrarily as having 100 units (u.) of activity $/ \mathrm{ml}$. Results obtained by this method were shown to be well correlated with those obtained by the viscosity method (see Results).

$\alpha$-L-Arabinofuranosidase ( $\alpha$-L-arabinofuranoside arabinohydrolase) (AF), pectin methyl-trans-eliminase (PTE) and macerating activity were estimated as described by Byrde \& Fielding (I968), who detected no polygalacturonate trans-eliminase in the culture filtrate.

Gel filtration. For molecular weight determinations $0 . \mathrm{I} \mathrm{M}-\mathrm{KCl}$ in $0.05 \mathrm{M}$-tris buffer $(\mathrm{pH} 7 \cdot 4$ ) was used for elution of a Sephadex $\mathrm{G} 75$ column (bead form) following the method of Andrews (1964) and basing the standard curve on nine proteins; $3 \mathrm{ml}$. fractions were collected. In other experiments, water was used for elution and $10 \mathrm{ml}$. fractions were collected.

Ion-exchange chromatography. This was done with CM-Sephadex gel (C.50) (Byrde \& Fielding, 1968) or Ecteola-cellulose. Before use, Ecteola-cellulose was washed successively with $\mathrm{N}-\mathrm{NaOH}, \mathrm{M}^{-} \mathrm{KH}_{2} \mathrm{PO}_{4}$ and $0 \cdot 0 \mathrm{I}$ M-phosphate buffer ( $\mathrm{pH} 7{ }^{\circ}$ ) to remove impurities showing high absorption at $280 \mathrm{~m} \mu$ (Bradley \& Rich, 1956). Elution was with water and $\mathrm{NaCl}$ solutions.

Paper chromatography. Breakdown products were examined on Whatman no. 54 paper with solvents ethyl acetate + acetic acid + water $(2+I+2$, by vol.; Jermyn \& Isherwood, I949) or $80 \%(\mathrm{w} / \mathrm{v})$ phenol in water. Spots were developed by spraying the papers with $p$-anisidine hydrochloride $(3 \%, \mathrm{w} / \mathrm{v}$, in butan-I-ol; Hough, Jones \& Wadman, 1950) or with silver nitrate (Trevelyan, Procter \& Harrison, 1950).

Electrophoresis on cellulose acetate strips followed the general method described by Kohn (I957). The enzyme solution ( $50 \mu \mathrm{l}$.) was streaked by successive applications with a micro-constriction pipette on a cellulose acetate strip $36 \times 5 \mathrm{~cm}$. (Oxoid Ltd., London) in a narrow band approximately $7 \mathrm{~cm}$. from the anode end. The voltage used was 300-400 V, d.c. giving a current of about $2 \mathrm{~mA}$ per strip, in $0.05 \mathrm{M}$-tris buffer $(\mathrm{pH} 7.6$ or 8.5$)$; electrophoresis was at room temperature. After running for approximately $8 \mathrm{hr}$ the sites of enzyme activity were detected in one of three ways: $(a)$ for PG, by inverting the moist strip on a plate of pectate agar gel (see estimation methods). After overnight incubation at $25^{\circ}$, the strip was removed and the plate developed with $6 \mathrm{~N}-\mathrm{HCl}$ to give discrete white zones; $(b)$ for AF, the moist strip was sprayed with an aqueous solution of $p$-nitrophenyl- $\alpha$-L-arabinofuranoside (I $\mathrm{mg} . / \mathrm{ml}$.), incubated for $\mathrm{I}$ hr at $25^{\circ}$ and laid on a filter paper moistened with saturated $\mathrm{Na}_{2} \mathrm{CO}_{3}$ solution for development of the yellow colour; $(c)$ alternatively, for semi-quantitative estimation of AF and PG, the strip was removed and divided transversely into segments I cm. wide, each of which was further cut into pieces about $2 \mathrm{~mm}$. across and soaked in I ml. o. I M-acetate buffer $(\mathrm{pH} 4 \cdot 7)$ for I hr. Samples were then removed for enzyme assay, using the agar plate method for PG.

\section{RESULTS}

Gel filtration and column chromatography. The initial culture filtrate contained PG, AF and PTE activities. The patterns of PG, AF and macerating activity when a crude culture filtrate was applied to Sephadex G 75 and eluted with water are shown in Fig. I. 
Appropriate fractions were dialysed overnight at $4^{\circ}$ against distilled water and applied to a column of Ecteola-cellulose. Elution with water followed by $0 \cdot \mathrm{I} \mathrm{M}-\mathrm{NaCl}$ resulted in the enzyme pattern shown in Fig. 2. When a crude culture filtrate was applied to a column of CM-Sephadex, followed by elution with a sodium chloride gradient, PG and AF were maximal in the early fractions. Macerating activity (due to PTE) followed in two peaks (Fig. 3 of Byrde \& Fielding, 1968).

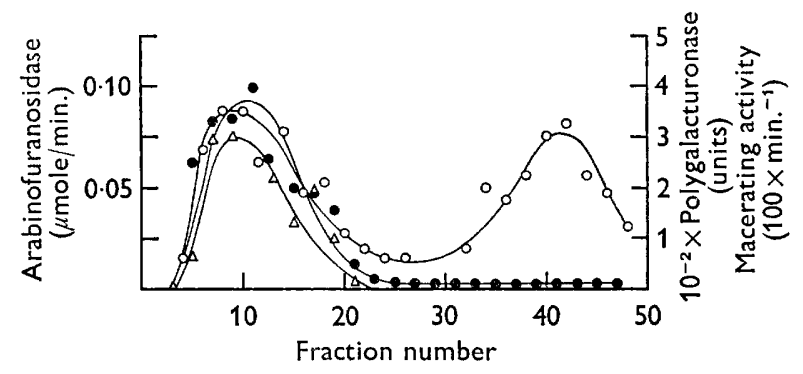

Fig. 1. Sclerotinia fructigena. Polygalacturonase $(\bullet)$, arabinofuranosidase $(\triangle)$ and macerating $(O)$ activity of fractions from aqueous elution of Sephadex G 75 dextran gel.

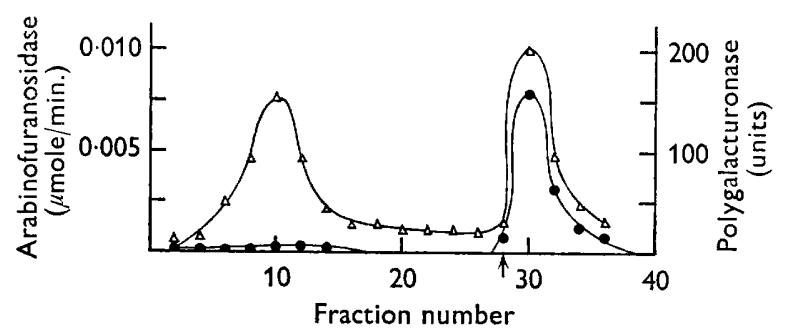

Fig. 2. S. fructigena. Polygalacturonase $(\bullet)$ and arabinofuranosidase $(\triangle)$ activities of fractions from Ecteola-cellulose eluted first with water and then (from arrow) with $0 \cdot \mathrm{I} \mathrm{M}-\mathrm{NaCl}$.

CM-Sephadex and Ecteola-cellulose column chromatography were used successively for partial purification of PG and AF, to give purification factors of $6 I$ and $>24$ respectively, and elimination of all but traces of the other enzymes.

For PG, CM-Sephadex was used initially, enabling the PTE component to be eliminated. When dialysed fractions high in PG and AF activity were then passed through Ecteola-cellulose, PG activity was retained by the column and could be eluted in a sharp peak with $\mathrm{O} \cdot \mathrm{I} \mathrm{M}-\mathrm{NaCl}$. By contrast with the behaviour when fractions from Sephadex G 75 were applied to Ecteola-cellulose, AF activity was not present in the initial eluate, nor was it present in the $0 . \mathrm{I} \mathrm{M}-\mathrm{NaCl}$ eluates of high PG activity (Table I). The uronide concentration (McComb \& McCready, I952) was decreased from $1700 \mu \mathrm{g} . / \mathrm{ml}$. in the culture filtrate to $2 \mu \mathrm{g} . / \mathrm{ml}$. in fraction 26 .

For AF purification, the chromatography was done in reverse order. With a tannic acid preparation the PG was retained on the Ecteola-cellulose. The water eluate containing $58 \%$ of the AF activity was then applied to a CM-Sephadex column which enabled the AF to be separated from the PTE (Table 2).

Unsuccessful purification methods. Several techniques conventionally used for enzyme purification proved to be unsuitable for the purification of this PG. Poor recoveries 
氖:

풀요요 8

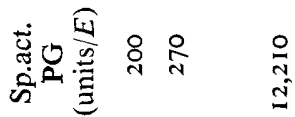

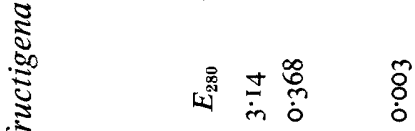

竞

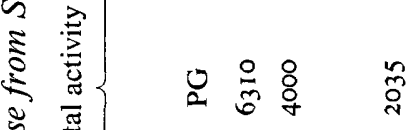

苋

密

8

2

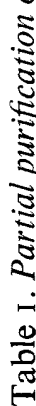

畩

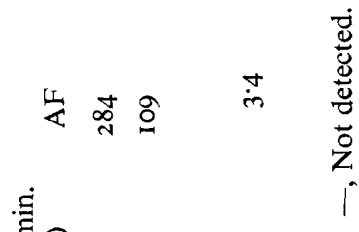

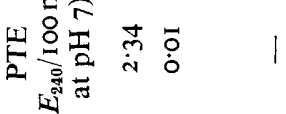

4

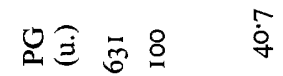

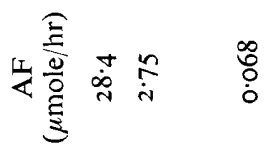

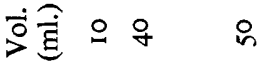

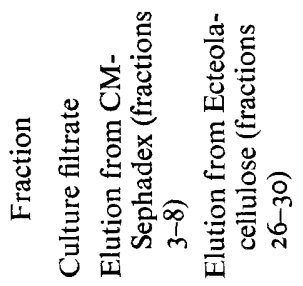

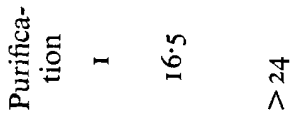

풀ㅇㅇㅇㅇㅢ

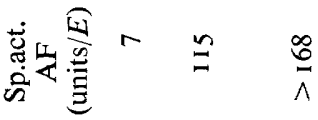

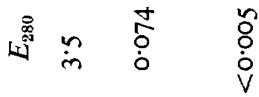

峁苛品 |

인 웅 일

एँ

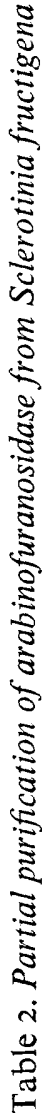

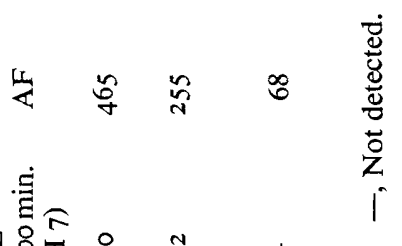

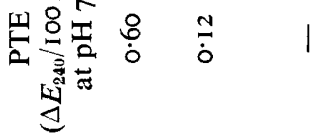

证兽=1

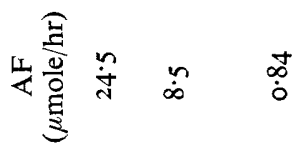

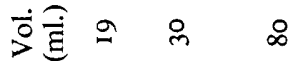

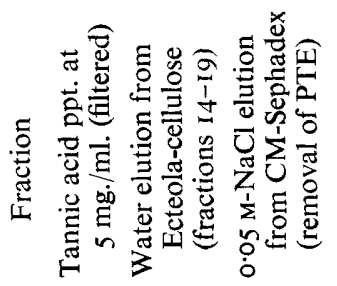


(about $33 \%$ ) from the culture filtrate were obtained with acetone, ethanol or ammonium sulphate precipitation, the latter being tried at a range of $\mathrm{pH}$ values. Adsorption on, and elution from, pectic acid gel (Demain \& Phaff, 1954) gave heavy polysaccharide contamination, whilst calcium phosphate gel, aluminium oxide and glass powder did not adsorb the enzyme. Bentonite adsorbed the activity but this could not be recovered. Of the modified celluloses, carboxymethyl cellulose gave poor adsorption of $\mathrm{PG}$, by contrast with the experience of Mill \& Tuttobello (I96I) with the PG of Aspergillus niger.

DEAE-cellulose appeared less useful than Ecteola-cellulose, whilst elution from TEAE-cellulose resulted in a plateau, rather than a peak, of activity. Zone electrophoresis on starch gel (Smithies, I955), agar gel or polyvinyl chloride gel (Kunkel \& Trautman, 1959) were ineffective: the enzyme remained at the starting line. The same difficulty was encountered with paper electrophoresis, although Purr, Hottenroth, Döring \& Schneider (I957) successfully separated two polygalacturonases from a commercial pectolytic enzyme by this method.

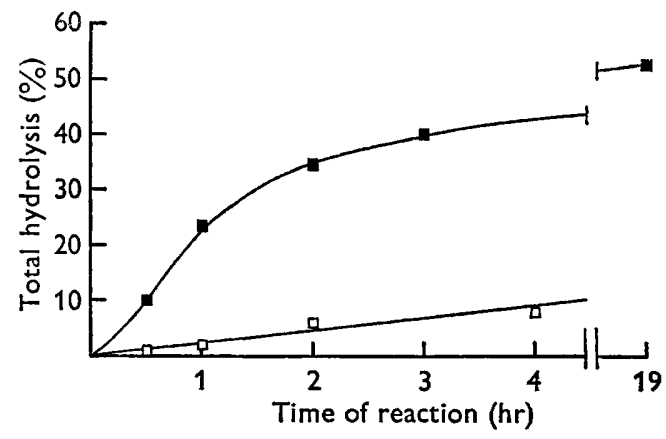

Fig. 3. Sclerotinia fructigena. Hydrolysis of $0.4 \%$ solutions of sodium polypectate ( $\boldsymbol{(})$ and pectin ( $\square$ ) measured by the release of reducing groups at $\mathrm{pH} 4 \cdot 7$.

\section{Properties of the enzymes}

$P G$. The PG preparations used for these experiments were $0 \cdot \mathrm{I} \mathrm{M}-\mathrm{NaCl}$ eluates from Ecteola-cellulose showing maximum PG activity; these were dialysed overnight at $4^{\circ}$. Figure 3 shows the time-course of liberation of reducing groups by PG with sodium polypectate and pectin as substrates. The pattern of the curves is very similar to that reported for an endo-PG from Aspergillus niger by Mill \& Tuttobello (196I) and shows that breakdown became very slow after $40 \%$ hydrolysis. Polypectate was more readily attacked than pectin; this was also found by the viscosity method. The viscosity of sodium polypectate solution $(0.5 \%)$ was halved in about I min.

$A F$. The relationship between time and $p$-nitrophenol liberated from $p$-nitrophenyl$\alpha$-L-arabinofuranoside solution was linear only up to absorption values of approximately $0 \cdot 1$, corresponding to I $5 \%$ hydrolysis. This value was inevitably low because of the low concentration of substrate which was in short supply. By making estimations at a range of higher substrate concentrations, the Lineweaver-Burk plots obtained gave a $K_{m}$. value between 0.35 and $0.36 \mathrm{~mm}$ in each of two experiments. This compared with values of the order of $0.65 \mathrm{~mm}$ for the AF of Phytophthora palmivora (Akinrefon, 1968). 
Breakdown products. When a purified PG preparation was incubated at $25^{\circ}$ under toluene with sodium pectate or pectin (final concentration $16 \mathrm{mg}$. $/ \mathrm{ml}$.) no spot corresponding to D-galacturonic acid was detected after $48 \mathrm{hr}$, although two spots of lower $R_{r}$ value, which were probably oligouronides were observed, even after $8 \mathrm{hr}$; these

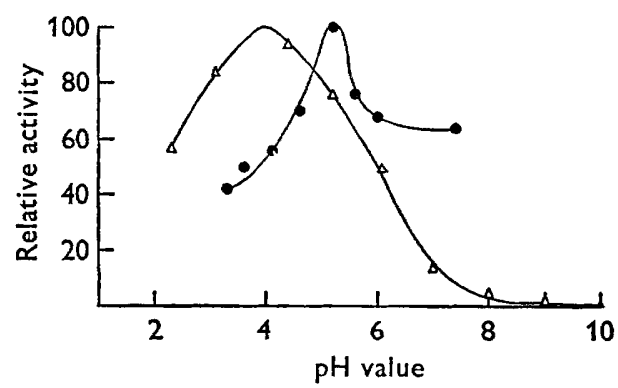

Fig. 4. S. fructigena. pH/activity relationships for polygalacturonase (๑) and arabinofuranosidase $(\triangle)$.

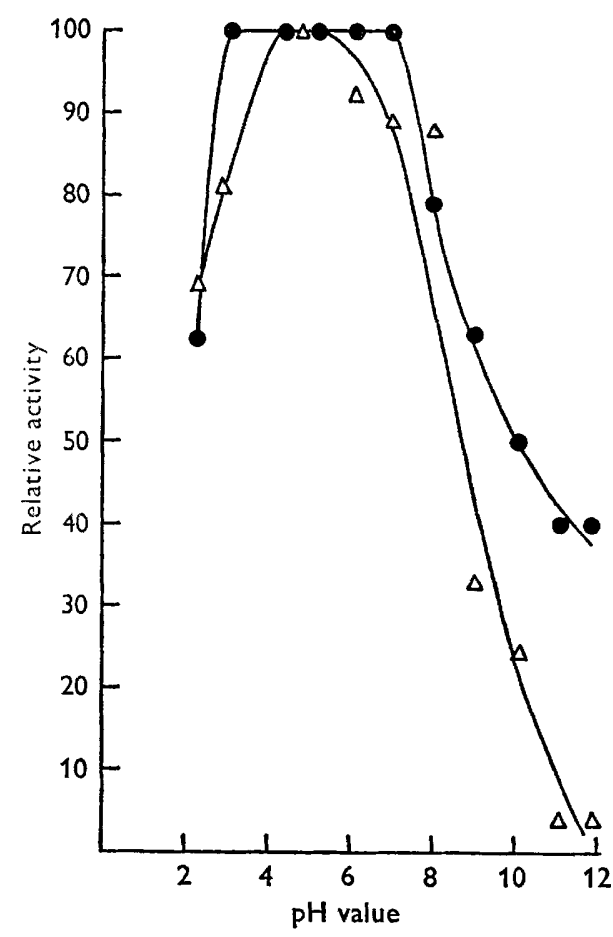

Fig. 5

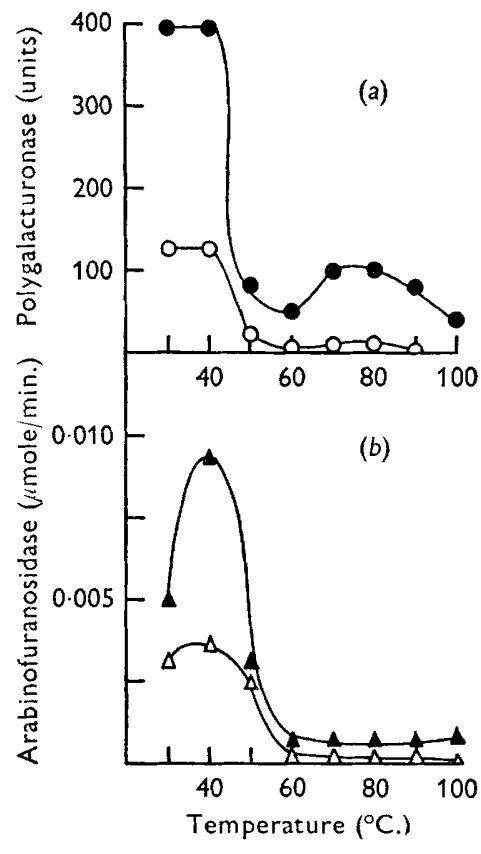

Fig. 6

Fig. 5. Sclerotinia fructigena. $\mathrm{pH} / \mathrm{stability}$ relationships for polygalacturonase (๑) and arabinofuranosidase $(\triangle)$ for $20 \mathrm{~min}$. exposure.

Fig. 6. S. fructigena. Thermal stability (20 min. exposure) of: (a) polygalacturonase in culture filtrate $(\bullet)$ and purified preparation $(O) ;(b)$ arabinofuranosidase in culture filtrate $(\boldsymbol{\Delta})$ and purified preparation $(\Delta)$. 
were more pronounced when sodium pectate was the substrate. Spots corresponding to glucose were also observed.

When a purified AF preparation was similarly incubated overnight with Araban or an apple fibre preparation, monomeric arabinose was detected, but no evidence of oligomers was obtained. A trace of arabinose was also detected when pectin was used as substrate.

$p H$ relationships. $\mathrm{PG}$ activity at a range of $\mathrm{pH}$ values was estimated by the reducing group method with sodium polypectate as substrate and acetate and phosphate buffers (final concentration $0.2 \mathrm{M}$ ). The results plotted in Fig. 4 were comparable with those found by Cole (1956) for Sclerotinia fructigena by the viscosity method with sodium polypectate as substrate, though with the peak of activity about one $\mathrm{pH}$ unit lower. AF activities estimated in the presence of citrate + phosphate + borate buffer are also shown in Fig. 4.

The effect of $\mathrm{pH}$ value on PG stability was examined over the range $\mathrm{pH} 2$ to 12 by mixing I vol. of the appropriate citrate + phosphate + borate buffer (Teorell \& Stenhagen, 1938) with 9 vol. of enzyme solution. After 20 min. at room temperature an equal volume of $0.2 \mathrm{M}$-acetate buffer $\left(\mathrm{pH}_{4} \cdot 7\right)$ was added. The decrease in PG activity assessed by the agar plate method is shown in Fig. 5, relative to untreated enzyme. The enzyme showed remarkable stability at small $\mathrm{pH}$ values and also up to pH I 8 . Figure 5 also shows comparable data for AF activity.

\section{Table 3. Sclerotinia fructigena: molecular weight of enzyme components estimated by gel-filtration}

\begin{tabular}{ccccccc} 
Enzyme & \multicolumn{9}{c}{ Elution vol. (ml.) } & Corresponding \\
mol.wt.
\end{tabular}

Temperature stability and effect of enzyme inhibitors. Samples $(2 \mathrm{ml}$.) in $20 \mathrm{ml}$. test-tubes were held at a range of temperatures for $20 \mathrm{~min}$., then cooled rapidly to about $0^{\circ}$ by immersion of the tube in acetone at $-25^{\circ}$. Residual PG activities were estimated viscometrically, and residual AF by the usual method. Figure 6 summarizes the data for each enzyme using both crude (culture filtrate) and purified preparations.

The PG activity of each sample was also estimated by the agar plate method. The results by the two methods in three experiments showed a highly significant correlation $(P<0.00 \mathrm{I})$. The equation relating the agar-plate value $(y)$ to the viscosity estimate $(x)$ was:

$$
y=2 \cdot 50 x \text {. }
$$

The inhibition of enzyme activity at $60^{\circ}$ was not prevented by gelatin ( $\mathrm{I} \mathrm{mg} . / \mathrm{ml}$.), cysteine $\left(\mathrm{IO}^{-3} \mathrm{M}\right)$, ethylenediaminetetra-acetic acid $\left(\mathrm{IO}^{-3} \mathrm{M}\right)$ or potassium cyanide $\left(\mathrm{IO}^{-4} \mathrm{M}\right)$.

Tests for polyphenol oxidase activity at room temperature and at $60^{\circ}$ were negative. 
Heating to $80^{\circ}$ for $20 \mathrm{~min}$., however, resulted in a more active preparation after a further $20 \mathrm{~min}$. at $60^{\circ}$ than a control sample heated only to $60^{\circ}$ for $20 \mathrm{~min}$.

Less than $20 \%$ inhibition of PG activity in fractions eluted from Sephadex G.75 occurred in the presence of the following: $\mathrm{KCN}, 8$-hydroxyquinoline, sodium diethyldithiocarbamate, sodium azide, iodoacetic acid, mepacrine, $o$-phenanthroline or 2,4-dinitrophenol (each at $\mathrm{IO}^{-3} \mathrm{M}$ ), diethyl p-nitrophenyl phosphate or di-isopropyl fluorophosphate (each at $\mathrm{IO}^{-4} \mathrm{M}$ ). Compounds were incubated for $\mathrm{I}$ hr with the enzyme before assay by the agar plate method at $\mathrm{pH} 4.7$. Under these conditions, mercuric chloride inhibited activity by $50 \%$ at ${ }_{10}^{-3} \mathrm{M}$ and by $34 \%$ at ${ }_{10}^{-4} \mathrm{M}$, p-chloromercuribenzoic acid by $57 \%$ at $10^{-3} \mathrm{M}$, and urea by $80 \%$ at $8 \mathrm{M}$.

When the enzyme was exposed as indicated below to proteolytic enzymes before assay, the following gave less than $20 \%$ inhibition: pepsin $\left(0.03 \mathrm{mg} . / \mathrm{ml} ., \mathrm{pH} 3,37^{\circ}\right.$. $30 \mathrm{~min}$.), papain $\left(0.03 \mathrm{mg} . / \mathrm{ml}\right.$, $\mathrm{pH} 6,37^{\circ}, 30 \mathrm{~min}$.), trypsin or chymotrypsin (each at $0.1 \mathrm{mg} . / \mathrm{ml} ., \mathrm{pH} 7.5,37^{\circ}, 2 \mathrm{hr}$ ). Exposure to 'Pronase' (secreted by Streptomyces griseus) (0.1 mg. ml., pH 7.4, 30, $24 \mathrm{hr}$ ) resulted in $30 \%$ loss of activity.

Molecular weight determination from Sephadex gel filtration data. One ml. of a dialysed freeze-concentrated culture filtrate of Sclerotinia fructigena was mixed with I $\mathrm{ml}$. eluant and applied to a calibrated Sephadex G 75 column. Molecular weight determinations (Andrews, 1964) in four experiments are summarized in Table 3. The form of AF with the smallest molecular weight was detected in only two of the four experiments.

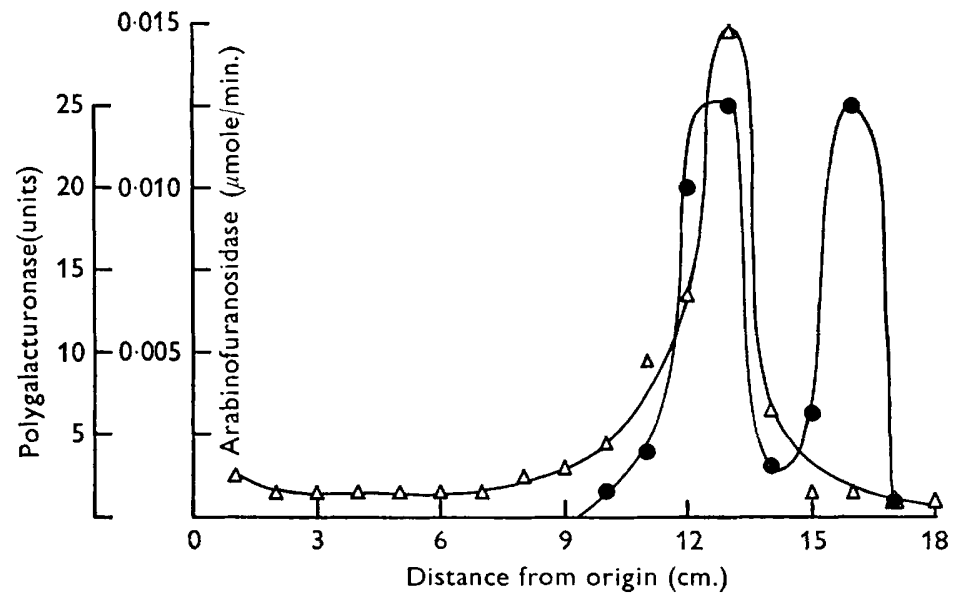

Fig. 7. Sclerotinia fructigena. Migration towards cathode of polygalacturonase (๑) and arabinofuranosidase $(\triangle)$ on electrophoretogram on cellulose acetate strips.

Electrophoresis on cellulose acetate strips. In experiments with crude culture filtrates, or various preparations from them, both enzymes migrated consistently towards the cathode. Best results were obtained by using a tannic acid preparation (Io mg. $/ \mathrm{ml}$.); when electrophoresis was done at $\mathrm{pH} 7 \cdot 6$, two $\mathrm{PG}$ peaks were detected, one being coincident with the single peak of AF activity (Fig. 7). A similar pattern was found in three other experiments at $\mathrm{pH} 7.6$ and also at $\mathrm{pH} 8.5$, although the faster running PG component was generally slightly less active than the slower running one. The peak of macerating activity of the fractions coincided with the joint peak of PG and AF. 


\section{DISCUSSION}

The polygalacturonase of Sclerotinia fructigena is apparently an endo-polygalacturonase Type I according to the classification of Demain \& Phaff (1957). Its ability to cause the rapid decrease in viscosity of sodium polypectate solutions with a slow release in reducing groups, together with the absence of D-galacturonic acid in incubation mixtures, is characteristic of this type of $\mathrm{PG}$. The more rapid hydrolysis of pectate than of pectin indicates that the enzyme is a polygalacturonase rather than a polymethylgalacturonase. The $\mathrm{pH} /$ activity relationships of the enzyme, with sodium polypectate as substrate, characterize it as being of Type I (optimum at relatively small $\mathrm{pH}$ value); it is in many respects similar to the endo-PG of Aspergillus niger described by Mill \& Tuttobello (I96I).

The Sclerotinia enzyme showed unusual stability over a wide range of $\mathrm{pH}$ values and was in general little affected by classical enzyme inhibitors. This is in accord with general experience with pectolytic enzymes (e.g. Husain \& Dimond, 1958). The enzyme is, however, readily inactivated by several polyphenolic compounds (Byrde, Fielding \& Williams, I960; Cole \& Wood, I96I) probably in a non-specific manner. It also resists breakdown by the highly versatile proteolytic enzyme from Streptomyces griseus (Nomoto, Narahashi \& Murakami, 1960).

McClendon (1964), who used a preparation from Sclerotinia fructigena, showed the existence of more than one component by ion-exchange chromatography. That such components may represent polymeric forms was indicated by the present results of the molecular weight estimation with a dialysed concentrated culture filtrate, which gave peaks corresponding to molecular weights of 38,500 and 77,000 . It may be significant that Swinburne \& Corden (1969) observed changes in the properties of a PG secreted by Penicillium expansum during purification by ion-exchange chromatography which they attributed to changes in the molecular configuration of the enzyme. Two forms of the Sclerotinia fructigena enzyme in the tannic acid preparation were also detected on strip electrophoresis; these were not further characterized, but both carried a strong overall basic charge at $\mathrm{pH}_{7} .6$ and $\mathrm{pH} 8.5$. This basic character is likely to assist in the adsorption of the enzyme on the acidic polyuronides of the plant cell wall.

The temperature inactivation pattern of the crude Sclerotinia fructigena PG shows an unusual bimodal curve, reminiscent of that obtained for a proteolytic enzyme by Virtanen (1934) and with the PG's of Botrytis cinerea and Erwinia aroideae by Jarvis (1953). Virtanen ascribed these effects to complexing with other proteins. It may, however, be significant that with the purified preparation from S. fructigena (which, by contrast with the crude PG, was very low in uronide content) the second peak of activity at higher temperatures was much decreased. Alternatively, depolymerization by heat of a component in the crude culture filtrate into two molecules of lower polymers might be involved.

The $\alpha$-L-arabinofuranosidase appears to be a typical glycosidase attacking araban by a terminal mechanism to liberate the monomer as did the arabanases from Aspergillus species described by Kaji, Taki, Shimazaki \& Shinkai (I963). By contrast, arabanase from Sclerotinia libertiana liberated small quantities of oligomers in addition to monomer (Kaji et al. 1965). The $S$. fructigena enzyme is specific for the furanoside configuration (Byrde \& Fielding, I965), and its properties are in general similar to 
those of an AF from Phytophthora palmivora described by Akinrefon (I968), although the $K_{m}$ value is appreciably lower.

By contrast with the PG from Sclerotinia fructigena the AF was appreciably inactivated at high $\mathrm{pH}$ values and showed a normal temperature inactivation pattern. Whilst one peak of activity was detected in a tannic acid preparation by strip electrophoresis, or in a culture filtrate by gel filtration with water elution, there was evidence of two and sometimes three peaks on gel-filtration of a freeze-concentrated preparation eluted with tris buffer containing $0.1 \mathrm{M}-\mathrm{KCl}$. Although the estimated molecular weights of the two smaller components showed no obvious numerical relationship, and that of the largest component could not be assessed with the dextran gel used, it is clear that, as with PG, the enzyme can exist in multiple forms which are readily interconverted.

We wish to thank Miss Celia Slowley and Mrs M. Gooday for valuable technical assistance, and Mr G. M. Clarke for the correlation analysis.

\section{REFERENCES}

AkInREFon, O. A. (I968). Studies on the $\alpha$-L-arabinofuranosidase of Phytophthora palmivora (Butl.) Butl. New Phytol. 67, 543 .

ANDREws, P. (1964). Estimation of the molecular weights of proteins by Sephadex gel-filtration. Biochem. J. 91, 222.

Bateman, D. F. \& Millar, R. L. (1966). Pectic enzymes in tissue degradation. A. Rev. Phytopathology 4, 119.

Bradley, D. F. \& Rich, A. (I956). The fractionation of ribonucleic acids on ECTEOLA-Cellulose anion exchangers. J. Am. chem. Soc. 78, 5898 .

Bush, D. A. \& CoDNER, R. C. (1968). The nature of macerating factor of Penicillium digitatum Saccardo. Phytochem. 7, 863 .

Byrde, R. J. W. \& Fielding, A. H. (I962). Resolution of endopolygalacturonase and a macerating factor in a fungal culture filtrate. Nature, Lond. 196, I 227.

Byrde, R. J. W. \& Fielding, A. H. (1965). An extracellular $\alpha$-L-arabinofuranosidase secreted by Sclerotinia fructigena. Nature, Lond. 205, 390.

Byrde, R. J. W. \& Fielding, A. H. (1968). Pectin methyl-trans-eliminase as the maceration factor of Sclerotinia fructigena and its significance in Brown Rot of apple. J. gen. Microbiol. 52, 287.

Byrde, R. J. W., Fielding, A. H. \& Williams, A. H. (1960). 'The role of oxidised polyphenols in varietal resistance of apples to brown rot'. In Phenolics in Plants in Health and Disease. Ed. by J. B. Pridham, p. 95. Oxford: Pergamon Press.

Calonge, F. D., Fielding, A. H., Byrde, R. J. W. \& Akinrefon, O. A. (1969). Changes in ultrastructure following fungal invasion and the possible relevance of extracellular enzymes. $J$. exp. Bot. 20, 350.

Cole, J. S. (I956). Studies in the physiology of parasitism. XX. The pathogenicity of Botrytis cinerea, Sclerotinia fructigena and Sclerotinia laxa, with special reference to the part played by pectolytic enzymes. Ann. Bot. N.S. 20, 15.

COLE, M. \& WoOD, R. K.S. (I96I). Pectic enzymes and phenolic substances in apples rotted by fungi. Ann. Bot. N.s. 25, 435 .

Demain, A. L. \& Phaff, H. J. (1954). Composition and action of yeast polygalacturonase. Nature, Lond. I74, 515.

Demain, A. L. \& Phaff, H. J. (I957). Recent advances in the enzymic hydrolysis of pectic substances. Wallerstein Labs Commun. 20, I19.

De Bary, A. (I886). Über einige Sclerotinien und Sclerotinienkrankheiten. Bot. Ztg 44, 409.

Dingle, J., ReID, W. W. \& Solomons, G. L. (I953). The enzymic degradation of pectin and other polysaccharides. II. Application of the 'cup-plate' assay to the estimation of enzymes. $J$. Sci. Fd Agric. 4, I 49. 
Dixon, M. \& WeBb, E. C. (1958). Enzymes. London: Longmans, Green and Co.

Fielding, A. H. \& Hough, L. (1965). The synthesis of $p$-nitrophenyl- $\alpha$-L-arabinofuranoside. Carbohydrate Res. I, 327.

Fuchs, A., Jobson, J. A. \& WonTs, W. N. (1965). Arabanases in phytopathogenic fungi. Nature, Lond. 206, 7 I4.

Hough, L., Jones, J. K. N. \& Wadman, W. H. (I950). Quantitative analysis of mixtures of sugars by the method of partition chromatography. V. Improved method for the separation and detection of the sugars and their methylated derivatives on the paper chromatogram. J. chem. Soc. 1702.

Husain, A. \& Dimond, A. E. (I958). The function of extracellular enzymes of Dutch elm disease pathogen. Proc. natn. Acad. Sci. U.S.A. 44, 594.

JANSEN, E. F. \& MACDONnEll, L. R. (1945). Influence of methoxyl content of pectic substances on the action of polygalacturonase. Archs Biochem. Biophys. 8, 97.

JARVIS, W. R. (1953). A comparative study of the pectic enzymes of Botrytis cinerea Pers. and Bacterium aroideae Town., plant pathogens of the soft rotting type. Ph.D. Thesis, University of London.

JERMYN, M. A. \& IsHeRWOOD, F. A. (I949). Improved separation of sugars on the paper partition chromatogram. Biochem. J. 44, 402.

KajI, A., Tagawa, K. \& Motoyama, K. (I965). Studies on the enzymes acting on araban. VII. Properties of arabanase produced by plant pathogens. J. agric. chem. Soc. Japan 39, 352.

Kaji, A., Taki, H., Shimazaki, A. \& Shinkai, I. (1963). Studies on the enzymes acting on arabans. II. Action and separation of arabanase produced by Aspergilli. Tech. Bull. Fac. Agric. Kagawa Univ. Japan 15, 34.

KoHN, J. (1957). A cellulose acetate supporting medium for zone electrophoresis. Clinica chim. Acta 2, 297.

Kunkel, H. G. \& Trau'tman, R. (I959). Zone electrophoresis in various types of supporting media. In Electrophoresis. Ed. by M. Bier, p. 225. New York and London: Academic Press.

MCCLENDON, J. H. (1964). Evidence for the pectic nature of the middle lamella of potato tuber cell walls based on chromatography of macerating enzymes. Am. J. Bot. 51, 628 .

MCCOMB, E. A. \& MCCREADY, R. M. (1952). Colorimetric determination of pectic substances. Analyt. Chem. 24, I630.

Mill, P. J. \& TutTobel.o, R. (1961). The pectic enzymes of Aspergillus niger. II. Endopolygalacturonase. Biochem. J. 79, 57 .

Nomoto, M., Narahashi, Y. \& MuRaKami, M. (1960). A proteolytic enzyme of Streptomyces griseus. VI. Hydrolysis of protein by Streptomyces griseus protease. J. Biochem., Tokyo 48, 593 .

Purr, A., Hottenroth, B., Döring, M. \& Schneider, F. (1957). Polygalacturonases. Biochem. Z. $329,26 \mathrm{I}$.

Shibata, Y. \& Nisizawa, K. (I965). Microheterogeneity of $\beta$-glycosidases in apricot emulsin. Archs Biochem. Biophys. I09, 516.

SMITHIES, O. (1955). Zone electrophoresis in starch gels: group variations in the serum proteins of normal human adults. Biochem.J. 6r, 629 .

Swinburne, T. R. \& CoRden, M. E. (1969). A comparison of the polygalacturonases produced in vivo and in vitro by Pencillium expansum Thom. J. gen. Microbiol. 55, 75 .

TeOrell, T. \& STENhagien, E. (1938). Ein Universalpuffer für den pH-Bereich 2,0 bis I2,0. Biochem. Z. 299,416 .

Trevelyan, W. E., Procter, D. P. \& Harrison, J. S. (1950). Detection of sugars on paper chromatograms. Nature, Lond. I66, 444.

VAlleaU, W. D. (I9I 5). Varietal resistance of plums to brown rot. J. agric. Res. 5, 365 .

VirTANEN, A. I. (1934). On the enzymes of bacteria and bacterial metabolism. J. Bact. $28,447$.

WiltShIRE, S. P. (I920). The production of conidia in pure culture by the brown-rot fungus of the apple. Rep. agric. hort. Res. Stn. Univ. Bristol 1919, p. 34.

WooD, R. K. S. (1955). Pectic enzymes secreted by pathogens and their role in plant infection. Symp. Soc. gen. Microbiol. 5, 263.

Wood, R. K. S. (1960). Pectic and cellulolytic enzymes in plant diseases. A. Rev. Pl. Physiol. rI, 299.

Wormald, H. (1954). The Brown Rot Diseases of Fruit Trees, p. 38. London: H.M.S.O. 